\title{
Bilim Kurgu Filmlerinde İç Mekân Özelinde Görsel Manipülasyona Dair Okumalar: Matrix Örneği
}

\author{
Burcu Yıldırım ${ }^{1 *}$ \\ Doç. Dr. Deniz Demirarslan ${ }^{2}$
}

Geliş tarihi: 09.12.2019

Kabul tarihi: 26.12.2019

\section{Atıf bilgisi: \\ IBAD Sosyal Bilimler Dergisi \\ Sayı: $6 \quad$ Sayfa: 68-86 \\ Yıl: 2020 Dönem: Kış}

This article was checked by iThenticate. Similarity Index $2 \%$

Bu makalede araştırma ve yayın etiğine uyulmuștur.

${ }^{1}$ Kocaeli Üniversitesi, Türkiye, burcuyldrm3@hotmail.com, ORCID ID 0000-0002-7128-6080

2Kocaeli Üniversitesi, Türkiye, denizd@kocaeli.edu.tr

ORCID ID 0000-0002-7817-5893

*Sorumlu yazar
ÖZ

İç mekân, bireyi görsel olarak etkileyebilecek çeşitli unsurlar barındırmaktadır. $\mathrm{Bu}$ nedenle mekânlarda bireyleri, görsel alg1 yolu ile manipülasyon kavramı bağlamında etkileyebilmek mümkündür. Bilim kurgu sineması ise, ortaya koyduğu veriler ile geleceğe dair argümanlar sunabilmektedir. Yapılan bu çalışmada, bilim kurgu sineması ile iç mekân tasarımı-manipülasyon ilişkisine yeni bir bakış açısı sunmak amaçlanmaktadır. Böylelikle araştırmacıların, geleceğin mekânlarında kullanılacak olan mekânsal manipülasyonlara dair öngörülerde bulunabilmeleri sağlanabilecektir. Çalışmada öncelikle; görsel algı, görsel algıyı oluşturan öğeler, görsel algı-manipülasyon ilişkisi ve iç mekân tasarımında manipülatif etkilerin oluşturulma yöntemlerine dair kavramlardan bahsedilerek teorik arka plan oluşturulmuştur. Daha sonra iç mekân tasarımında manipülatif etkilerin geleceğine dair okumaların yapılmasına olanak sağlayabileceğinin düşünüldüğü bilim kurgu filmlerine yönelinmiştir. Bu bağlamda çeşitli çevrelerce bilim kurgu sinemasında bir kırılma noktası yarattı̆̆ ifade edilen ve aslında hikayesi de algısal manipülasyon üzerine kurulu olan Matrix film serisi seçilmiştir. Bunun yanında film, mekân ve manipülasyon hususunda ortaya koyduğu verilerle de dikkat çekicidir. Bu nedenle çalışmada Matrix serisi üzerine yoğunlaşılmış ve mekânsal manipülasyona dair en çok veri içerdiği düşünülen serinin birinci filmi 'Matrix' üzerinde çalışılmıştır. Daha sonra literatürde yer alan iç mekân tasarımı-manipülasyon ilişkisine dair yapılan çalışmalar incelenmiştir. Bu çalışmalardan, iç mekân tasarımında manipülatif etkilerin oluşturulma yöntemlerine dair uygun bulunan bir sınıflandırma yöntemi seçilen filmin analizi için kullanılmıştır. Filmdeki manipülasyon kapsamında incelenmeye uygun görülen iç mekân içerikli sahnelerin irdelenmesi bu yolla gerçekleştirilmiştir. Böylelikle; Matrix filmi üzerinden bilim kurgu filmlerinde sunulan iç mekânların bireyler üzerinde hangi yollarla manipülatif etkiler oluşturabileceği araştırılmış, tablolaştırılarak yorumlanmaları gerçekleştirilmiştir.

Anahtar Kelimeler: Görsel Algı, Manipülasyon, İç Mekân Tasarımı, İç Mekânsal Manipülasyon, Matrix 


\title{
Readings on Visual Manipulation in Interior Space in Science-Fiction Films: The Matrix
} Case

\author{
Burcu Yıldırım ${ }^{1^{*}}$ \\ Assoc. Prof. Dr. Deniz Demirarslan ${ }^{2}$
}

First received: 09.12.2019

Accepted: 26.12.2019

Citation:
$\begin{array}{ll}\text { IBAD Journal of } & \text { Social Sciences } \\ \text { Issue: } 6 & \text { Pages: } 68-86 \\ \text { Year: } 2020 & \text { Session: Winter }\end{array}$

This article was checked by iThenticate. Similarity Index $2 \%$

\section{${ }^{1}$ Kocaeli Universitiy, Turkey, burcuyldrm3@hotmail.com,} ORCID ID 0000-0002-7128-6080

${ }^{2}$ Kocaeli Universitiy, Turkey, denizd@kocaeli.edu.tr, ORCID ID 0000-0002-7817-5893

\section{* Corresponding Author}

\begin{abstract}
The interior contains various elements that can affect people visually. Therefore, it is possible to influence individuals in the context of the concept of manipulation through visual perception. On the other hand, sci-fi cinema can present arguments for the future with the data it presents. In this study, it is aimed to present a new perspective on the relationship between science fiction cinema and interior designmanipulation. In this way, researchers will be able to predict the spatial manipulations that will be used in the spaces of the future. Firstly; the theoretical background was created by mentioning the concepts of visual perception, the elements that make up visual perception, the relationship between visual perception and manipulation and the methods of creating manipulative effects in interior design. Afterwards, science fiction films which are thought to enable reading about the future of manipulative effects in interior design are examined. In this context, the Matrix film series, which is said to create a breaking point in science fiction cinema by various circles and is based on perceptual manipulation, is chosen. In addition, this film is remarkable with its data on space and manipulation. For this reason, the focus is on the Matrix series and the first film of the series, which is thought to contain the most data on spatial manipulation, is studied. Then, the studies on the relationship between interior design and manipulation in the literature are examined. A suitable classification method from these studies, related to the methods of creating manipulative effects in interior design was used for the analysis of the selected film. In this way, the examination of the scenes with the interior content deemed suitable for examination within the scope of the manipulation in the film was carried out. Thus; the ways in which the interiors presented in the science fiction films could create manipulative effects on individuals were investigated through the Matrix film and tabulated and interpreted.
\end{abstract}

Keywords: Visual Perception, Manipulation, Interior Design, Interior Manipulation, Matrix 


\section{GİRIŞ}

“Aklıma bir fikir gelince onu önce hayalimde canlandırıyorum, düşünce yapısını değiştiriyorum, fikri iyileştiriyorum ve yapacağım aletin nasıl çalışacağını zihnimde canlandırıyorum... Bu sayede hiçbir şeye dokunmadan hizlıca eksiksiz tasarımlar yapabiliyorum. Kafamda oluşturduğum her türlü gelişmeyi icadıma uygulayıp hiçbir hata görmediğimde, beynimin ürettiği bu aleti somut bir şekle sokuyorum" (Tesla, 2017, s. 14).

Nikola Tesla ${ }^{1}$

Tesla'nın ifadesinde de belirtmiş olduğu üzere, tasarımcılar tasarıma dair öğeleri öncelikle zihinlerinde görmekte ve burada biçimlendirmektedirler. Bu durum, tasarımcılar için bir çeşit düşünce yolu ile tasarım yöntemidir. Zihin bu durumda adeta tasarımın deneyimlendiği yeni bir mekân haline gelmektedir. Bazı tasarımcılar için ise, bu durum öyle boyutlara varmıştır ki, tasarıma dair tüm etkinlikler bu zihin ortamında gerçekleşmektedir. Ve daha sonra tasarım yine bu zihinsel ortamda sonuçlanmaktadır. Bu zihnin yaratımı tasarım mekânına dair tasarımcı nesnel yargılara sahip değildir. Bahsedilen zihinsel mekân, yaşanılan dünyaya ait olmamakla birlikte aslında ondan kopuk da sayılamamaktadir.

Sinema ve animasyon gibi iki boyutlu aktarım yolları ile kişiye üç boyut algılatımında bulunan görsel ürünler, çoğunlukla var olmayan fakat var olabilecek nitelikte mekânlara dair izleyiciye bilgi aktarımında bulunmaktadırlar. Bu açıdan bakıldığında görsel sanatlar mekân tasarımcıları için adeta zihnin sunduğu tasarım mekânı eşdeğerinde yeni bir deneyim ortamı sunmaktadır. Bu durum ise, görsel sanatlar ve iç mekân tasarımı arasındaki ilişkiyi gözler önüne sermektedir ve özellikle sinemanın bu konuda önemli bir rolü bulunmaktadır.

Sinema geleneksel yazılı ve sözlü dilden değişik yönleri olan; kendine özgü kuralları, özellikleri bulunan: hem göze hem kulağa seslenen görsel- işitsel bir dildir. Aynı zamanda sinema bir anlatım, bir iletişim, bir propaganda, eğlence aracıdır (Özön, 1985, s.12-13). Sinema ayrıca bir araştırma, eğitimöğretim aracıdır. Özön'ün (1984, s.8) ifadesine göre; sinema bütün sanatların bireşimi, bir çeşit 'tüm sanat' sayılabilir. Bütün diğer sanatlardan sonra ortaya çıkan, bundan dolayı 'yedinci sanat' adını alan sinema, bu geleneksel sanatların hepsine açık ve yatkın olması, hepsini özümleyebilme niteliği taşıması yönünden tüm sanatı gerçekleştirebilecek tek sanattır. Sinema, anlatacağı hikâyeyi izleyicisine mekân bağlamında aktaran bir görsel sanat ürünüdür. Sinemadaki mekânsal unsurlar; sinema ürününün ortaya konulduğu dönemin sosyal ve kültürel hayat1, dönemin geleceği nasıl gördüğü gibi konularda araştırmacılara okumalar yapma olanağı sağlamaktadır. Sinema ürününde çeşitli mekânsal unsurlar kullanılarak anlatılmak istenen hikâye ve hikâyenin alt metni izleyiciye aktarılmaktadır. Sinema ürününde kullanılan bu mekânsal unsurlardan biri de manipülasyon teknikleri olarak görülmektedir. $\mathrm{Bu}$ teknikler ile sinema ürününde anlatılmak istenilen hikâye güçlendirilebilmekte ve hikâyenin alt metni izleyiciye doğru bir biçimde aktarılabilmektedir. Sinema ürününde mekânsal manipülasyon öğelerinin en çok kullanıldığı türlerden biri de bilim kurgu filmleridir.

Bilim ve hayal gücünün birleşiminden oluşan bilim kurgu filmlerinin (Bektaş, 2017, s. 203) geleceği kurgulaması hususu dikkat çekicidir. Örneğin; 1968 yılında Sutherland ${ }^{2}$ kafaya takılan bir ekran için ilk kez 'sanal gerçeklik' ifadesini kullanmıştır. Daha sonra 2012 yılına gelindiğinde Palmer Luckey ${ }^{3}$ Oculus adlı kafaya takılan bir ekran için fon arayışına girmiştir. Sanal gerçekliğe dair bu iki kırılma noktası arasında geçen 44 seneyi sorgulayan Schwab, bu durumun nedenlerinden birini de süreç içinde oluşan insan talebine bağlamaktadır. Bu süreçte en az iki kuşak bilim kurgu filmlerinde hayal edilenlerin gerçek olabileceği fikri ile büyümüştür. Daha sonra bu çocuklar büyüdüklerinde çeşitli uygulamalar, ağ sistemleri ve donanımlar tasarlayıp programlayabilmişlerdir (2019, s. 239). Bu durum, bilim kurgu filmlerinin geleceği şekillendirmedeki gücünü ortaya koymaktadır. Bektaş'ın eserinde ise (2017, s. 203) bilim kurgu filmlerinin var olmayan mekânları sunmaları veya ileri teknolojiyi işlemeleri bakımından yenilikçi filmler arasında sayılabileceği belirtilmiştir.

\footnotetext{
${ }^{1}$ Nikola Tesla (1856-1943). Sırp kökenli Amerikalı mucit, elektrik ve makine mühendisi.

${ }^{2}$ Ivan Sutherland (1938- ). Ünlü bilgisayar bilimci.

${ }^{3}$ Oculus VR (Sanal gerçeklik) firmasının kurucusu.
} 
'Manipülasyon' son yıllarda sıkça kullanılan, ama genelde olumsuz anlamlarda değerlendirilen bir sözcüktür. Kelime anlamı olarak bakıldığında Türk Dil Kurumu Sözlüğ̈̈’ne göre manipülasyon; yönlendirme, seçme-ekleme ve çıkarma yolları ile var olan bilgileri değiştirme olarak tanımlanabilmektedir. Adolf Portmann'a ${ }^{4}$ göre ise "Manipülasyon, insan olmanın en temel olgularından birisidir" (Kirschner, s.23). Kısaca kişinin veya kişilerin, istenildiği gibi düşünmesini, istenildiği gibi davranmasını sağlayacak etkiler manipülasyon olarak tanımlanabilmektedir. İç mekân tasarımı ve iç mimarlık mesleği de manipülasyon tekniklerinden faydalanmaktadır. İç mimar yaratımı mekânları kullanan kişiler, her gün bu mekânlar tarafindan manipüle edilmekte ve böylelikle mekânlardan daha etkin bir biçimde faydalanabilmeleri sağlanmaktadır.

İç mekân tasarımcısı tarafından mekân tasarımı sunum tekniklerinde kullanılan perspektif öğeleri içeren çizimler de birer manipülasyon örneğidir. Bu gibi durumlarda göz çeşitli perspektif teknikleri ile manipüle edilmekte ve bireyde iki boyutlu bir düzlem yardımı ile üç boyut algısı oluşturulmaktadır.

Yılmaz'a göre mimari mekânda oluşturulmak istenilen manipülatif etkiler, mimari tasarım öğretileri yolu ile farklı şekillerle ve çeşitli tasarım öğeleri etkisi ile gerçekleşebilmektedir. Yılmaz, bu manipülatif etkilerin oluşturulma yöntemlerini üç ana başlık altında toplamaktadır. Bunlar: Görsel algılamanın temel özellikleri ile oluşturulabilen manipülatif etkiler, Gestalt kuramlarından yararlanılarak oluşturulabilen manipülatif etkiler ve tasarım öğelerinden faydalanılarak oluşturulabilen manipülatif etkilerdir (2004, s. 69). Yapılan bu çalışmada, incelenmeye uygun görülen sahneler, Yılmaz'ın sınıflandırma yöntemi aracılığı ile, sinema-iç mekân ara kesitinde gerçekleştirilecektir.

\section{GÖRSEL ALGI VE GÖRSEL ALGI ÖĞELERİ}

Görmek, sezgi ve bilgi ile eş anlama gelmektedir. Batı felsefesinde tarih boyunca görme olgusu, metaforiksel olarak anlama ile eşdeğer olarak görülmüş̧ür (Korsmeyer, 2003, s. 55). Günümüzde kişinin dış dünyaya dair bilgi edinme hususunda algısının yaklaşık 5/4'ünün göz uzvu tarafindan beyne iletilen bilgilerle gerçekleştiği bilinmektedir. Bu durum kişinin dış dünyaya dair algısının oluşumunda göz uzvunun ne derece önemli olduğunu ortaya koymaktadır.

Görsel algının nasıl oluştuğunu ifade etmeden önce, gözün görme işleminin fiziksel olarak nasıl gerçekleştiğinden kısaca bahsetmek, konunun daha iyi anlaşılmasına yardımcı olacaktır. Gözün en dışında saydam tabaka (kornea) bulunmaktadır. Korneanın ardından göz merceği yer almaktır. Kişi tarafindan görülecek olan nesnenin yaydığı 1şık, mercekten geçip retinada bir görüntü oluşturacak şekilde buraya odaklanmaktadır. Gözün, göz rengini oluşturan bölümü olan iris, gelen ışı̆̆ın miktarına göre açılıp kapanmaktadır. İrisin merkezinde bulunan siyah bölge ise göz bebeğidir. Kişi tarafindan bir nesneye bakıldığında, cisimden yansıyan 1şık gözbebeğinden geçerek göze ulaşmaktadır. Göz merceği 1şığı bir görüntü oluşturacak biçimde retinanın üzerine odaklamaktadır. Retinada oluşan bu görüntü terstir. Retinada bulunan sinir hücreleri, bu ters görüntüyü optik sinirler aracıllı̆ı ile beyne göndermektedir. Görme işlemi beyinde gerçekleşmektedir. Beyin ters görüntüyü düz hale çevirerek yorumlamakta ve böylelikle görme işlemi gerçekleşmektedir (Buğdayc1, 2008, s. 16) (Şekil-1).

\footnotetext{
${ }^{4}$ Adolf Portmaan (1897- 1982). İsviçreli zooloji uzmanı. Hayvanlarda sosyalleşme çalışmaları bulunmaktadır.
} 


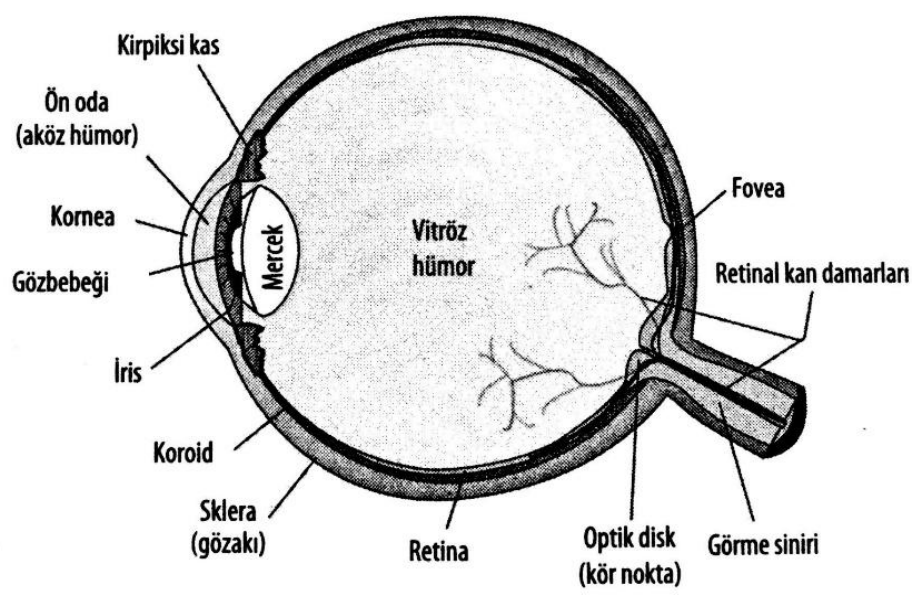

Şekil 1: İnsan gözünü oluşturan fizyolojik bölümler (Groh, 2017, s. 40).

İnsan kendisini saran uzamı, duyularının sağladığı enformasyonla algılamaktadır. Fakat duyular yalnızca bilme yetisi araçlar olarak görülmemelidir. Duyular sayesinde insan; hayatta kalabilmiş, tehlikelere karşı önlem alabilmiş ve güçlenerek yaşamına devam etmiştir. Bu süreç içerisinde duyular, bireyin hayatta kalması ve yaşamının sona ermesi arasındaki farkı belirleyen özelliklere odaklanmıştır. Bu durum; algının seçici ve amaca yönelik olarak işlev gördüğ̈̈nü göstermektedir (Arnheim, 2015, s. 35).

Algılama olayı kişinin beş duyu organı vasıtası ile gerçekleştirdiği bir durumdur. Bu duyu organlarından algılama hususunda en çok kullanılanı ise gözdür. Berger, bireyin düşündüklerinin ve inançlarının nesneleri görüşünü etkilediğini ifade etmektedir. $\mathrm{Bu}$ nedenle görmenin, uyarıcılara karşı mekanik bir tepki verip vermeme sorunu olmadığını, yalnızca bakılan şeylerin görüldüğünü, bakmanın ise bir seçme edimi olduğunu ifade etmektedir (2017, s. 8).

Görsel alg1; insanı çevreleyen nesnel dünyanın, bireyin duyuları vasıtası ile algılanıp, bilincinde anlamlandırılması işlemi olarak tanımlamaktadır. Fakat kişi tarafından algılanmış olan dünyanın nesnelliği ile çeşitli çevrelerce tartışılan bir konu olarak karşılaşmak mümkündür (Yılmaz, 2004, s. 3).

Bireyin yetiştiği kültür ve içinde yaşadığı toplumsal yapı, görsel algısında farklılıklara sebep olmaktadır. Algilama sürecine, kişisel özellikler yoğun bir biçimde etki etmektedir. Uyaranın önceden bilinmesi, kişinin zihinsel etkinliği, hayatı süresince edindiği deneyimler algı sürecinde etkili olmaktadır. Bunun yanında kişisel ilgi alanları, bireyin mensubu olduğu meslek grubu gibi olgular da görsel algı üzerinde etkili olmaktadır (Yıldırım, 2012, s. 38) (Şekil-2). 

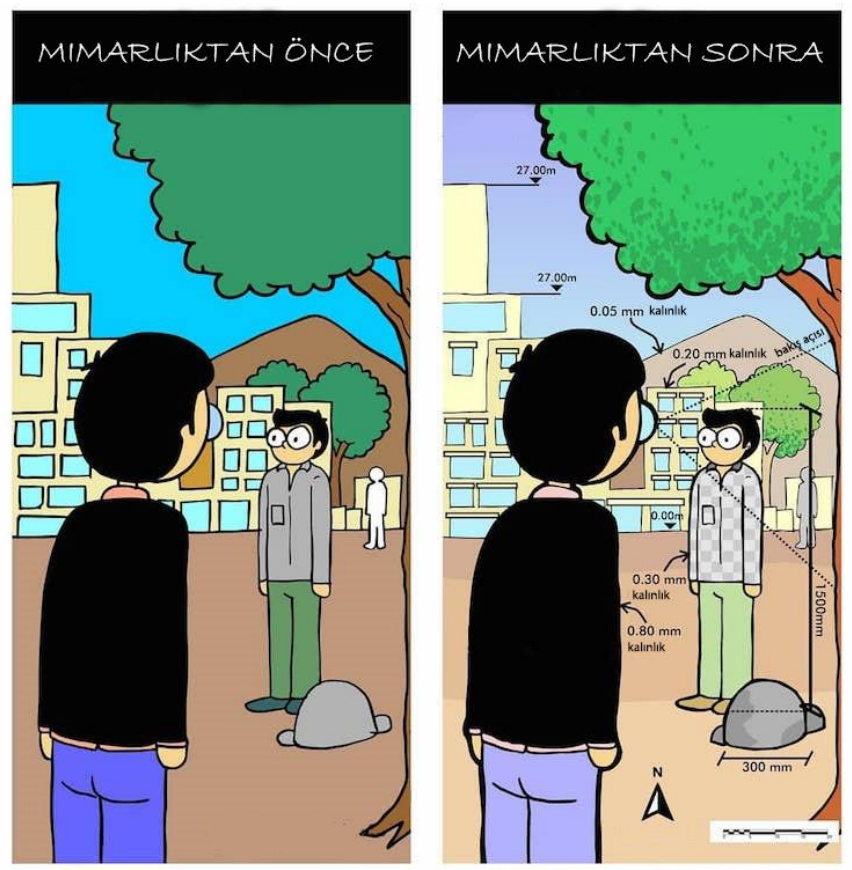

Şekil 2: Mimarlık meslek eğitiminin kişinin görsel algısı üzerinde yarattığı değişimi temsil eder görsel (URL-1).

\section{GÖRSEL ALGI VE MANIPÜLASYON İLİŞKİSI}

Görsel algı ve manipülasyon, birbiri ile bağlantılı iki kavramdır. İç mekân tasarımı olgusu da birbiri ile bağlantılı bu iki kavram arasındaki ilişkiden faydalanmaktadır. İç mekân tasarımı, görsel algı ve manipülasyon iliş̧kileri incelenmeden önce, görsel manipülasyonun tarihine kısa bir bakış atmak, araştırmacılar için konuya daha geniş bir perspektiften bakabilmek hususunda yararlı olacaktır.

Eski Mısır'da M.Ö.2200 yılına ait olduğu düşünülen 'Güreşçi' resmi aşamalı olarak bir olayı anlatırcasına insan hareketlerini göstermektedir. Adeta bir çizgi film hikâyesinin aşamaları çizilmişçesine, çizimlerle olay örgüsü anlatılmıştır (Kılıç, 2013, s. 104). Bunun yanında resmi güreş tekniklerinin sırası ile ifadesi şeklinde yorumlamak da mümkündür (Şekil-3).

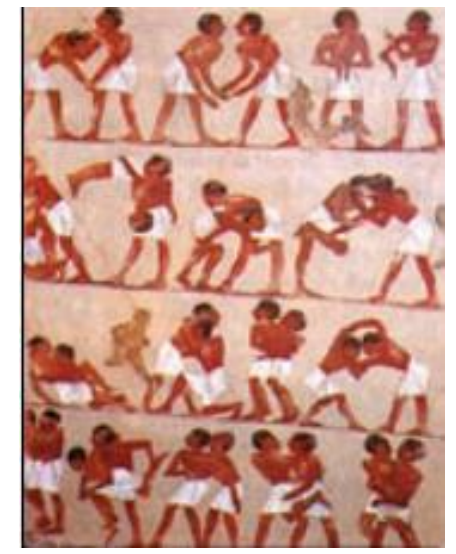

Şekil 3: M.Ö. 2200, Eski Mısır dönemi ‘Güreşçi’ resmi (URL-2).

Mimarlık ve resim sanatı eski çağlardan beri birbiri ile doğrudan ilişki içerisindedir. Bunu Alberti ${ }^{5}$ ve Brunelleschi $^{6}$ gibi mimarların çalışmalarında görmek mümkündür. Perspektifin keşfedilmesinden önce, iki boyutlu bir yüzeyde derinlik algısı yaratımı resim sanatı için oldukça büyük bir problem olarak görülmekteydi. Daha sonra bu problem Brunelleschi'nin çalışmaları ve ortaya koyduğu deneyle çözüme kavuşmuştur.

\footnotetext{
${ }^{5}$ Leone Battista Alberti (1404-1472). İtalyan mimar, ressam, filozof, dilbilimci ve müzisyen.

${ }^{6}$ Flippo Brunelleschi (1377-1446). İtalyan mimar, kuyumcu ve heykeltıraş.
} 
Brunelleschi tarafından 1425 yılında Floransa katedralinin önünde bir deney yapılmıştır. Katedralin vaftiz ayini bölümünün detaylı bir çizimi yapılmıştır. $35 * 35 \mathrm{~cm}$ boyutlarındaki bu çizimde, gökyüzü gümüş ayna sırı ile kaplanmıştır. Daha sonra doğrusal perspektifle çizilmiş bu resmin kaçış noktasına bir delik açılmıştır. Resmin önüne bir ayna tutularak izleyicinin delikten aynaya bakması istenmiştir. Denek delikten aynaya yansıyan resmin görüntüsünü ve resimdeki ayna sırına yansıyan gerçek gökyüzü görüntüsünü aynadan görmüştür. Böylelikle Brunelleschi bu deneyle, doğrusal perspektif tekniğini ortaya koyarken aynı zamanda iki boyutlu bir yüzey aracılığı ile izleyicide üç boyutlu bir algı yaratabilmiştir (Kılıç, 2013, s. 107). Bu deney ayrıca iki boyutlu bir yüzey aracılığı ile üç boyutlu hareketli bir görüntü oluşturabilmenin mümkün olduğunu göstermesi açısından da oldukça önemlidir (Şekil-4).

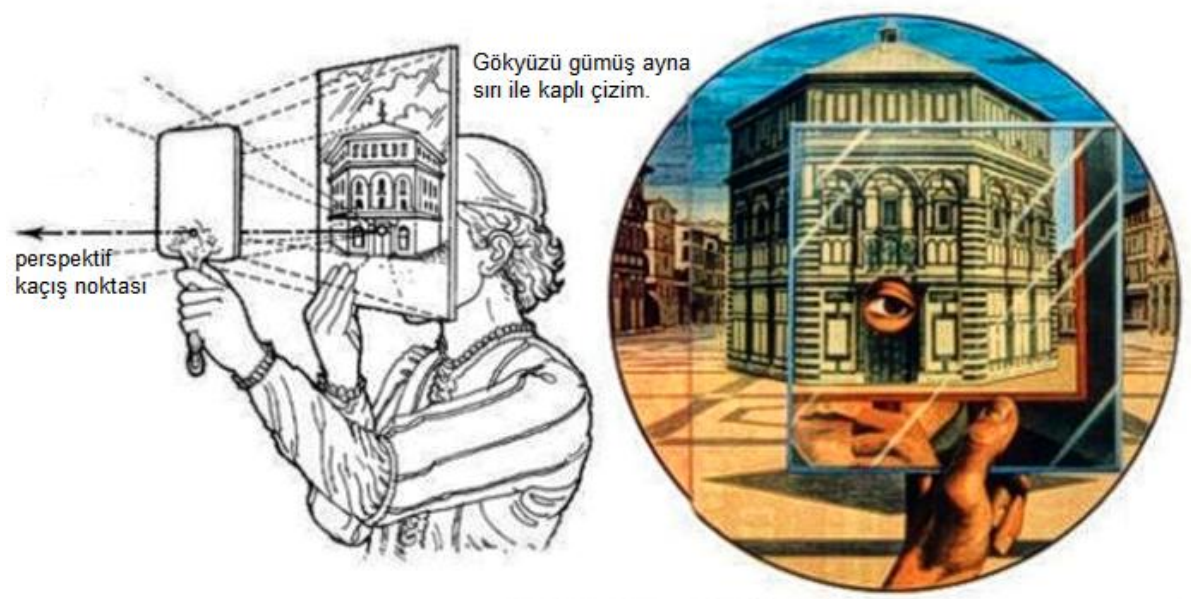

Şekil 4: Brunelleschi ayna deneyi temsili görseller (URL-3).

Perspektif geleneğinde her şey bakan kişinin görüş açısına göre düzenlenmektedir. Bu tekniği deniz fenerinden çıkan 1şınlara benzetmek mümkündür. Fakat ışıllar deniz feneri örneğinin tersine, içeri doğru ilerlemektedir. Bu gelenek, tek bir gözü görünen nesneler dünyasının odak noktası haline getirmektedir. Görünenler dünyası resmin uzamında evrenin tanrıya göre düzenlenmesi gibi seyirciye göre düzenlenmektedir (Berger, 2017, s. 16).

İnsan gözünün çalışma sistemine dair bilgiler geliştikçe, 1800'lü yıllarda görme duyusu ile ilintili aygıtlar ortaya çıkmıştır. Optik veya felsefi oyuncaklar olarak adlandırılabilen bu aygıtlar, kısa aralıklarla algılanan görsel duyumların, görme sistemi içinde işlenmesi sonucu, görülen nesnenin olduğundan farklı

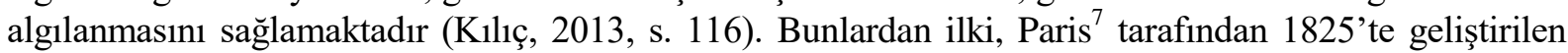
thomitrop (thaumatrope) 'tur. Thomitrop her iki yüzünde de birbiri ile ilintili resimlerin olduğu bir diskten oluşmaktadır. Diskin her iki yanında ipler bağlıdır ve bu disk çevrildikçe iki yüzeyindeki resimler tek bir düzlemde birleşerek farklı bir görüntü ortaya koymaktadır. Herhangi bir nesne, kişi tarafindan görüldüğünde, nesnenin kişinin retinası üzerindeki görüntüsü, nesne görme alanından çıktıktan sonra retina üzerinde yaklaşık 1/20 sn. kadar kalmaktadır. Yani nesne görüldükten sonra, belli bir süre daha görülmeye devam etmektedir. Bu duruma görmenin sürekliliği/devamı kuralı denilmektedir (Kılıç, 2013, s. 116). Thomıtrop aygıtı görmenin sürekliliği kuralından faydalanmaktadır (Şekil-5 ve Şekil-6).

\footnotetext{
${ }^{7}$ John Ayrton Paris (1785-1856). İngiliz asıllı doktor.
} 


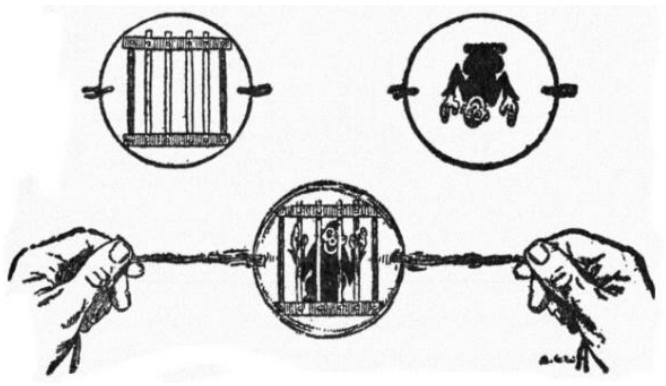

Şekil 5: Thomıtrop çalışma mantığı (URL-4).

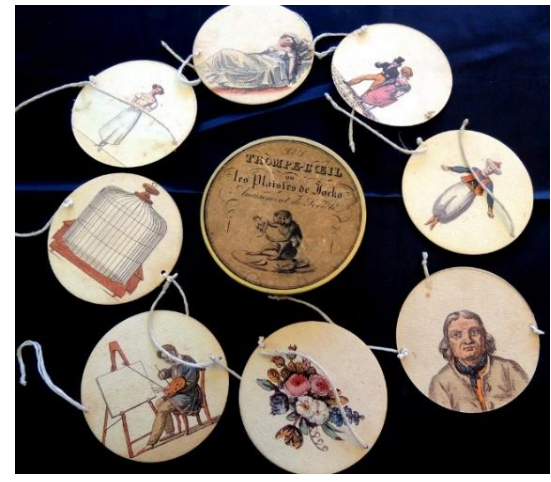

Şekil 6: Çeşitli görsellikte Thomitroplar (URL-

$5)$.

Yine o dönemlerde 1833 yılına gelindiğinde; Plateau ${ }^{8}$ ve Stampfer ${ }^{9}$ tarafından birbirinden bağımsız ve neredeyse eş zamanlı olarak fenakistiskop (phenakistoscope) icat edilmiştir (URL-6). Aygit, bir diskin üzerinde birbirine eș aralıklarla bölümlenmiş göz yuvalarından ayna yardımı ile diskin gözlemlenmesi yolu ile kullanılmaktadır. Örneğin diskin üzerindeki resimler bir atın koşarken aldığı halleri göstermektedir. Kişi bu resimleri disk dönerken, disk üzerindeki göz yuvaları yardımı ile aynadan gözlemlemektedir. Aynaya yansıyan görüntü ise kişinin görsel algısını manipüle ederek, kişide atın hareket ettiğine dair bir algı oluşturmaktadır (Şekil-7 ve Şekil-8).

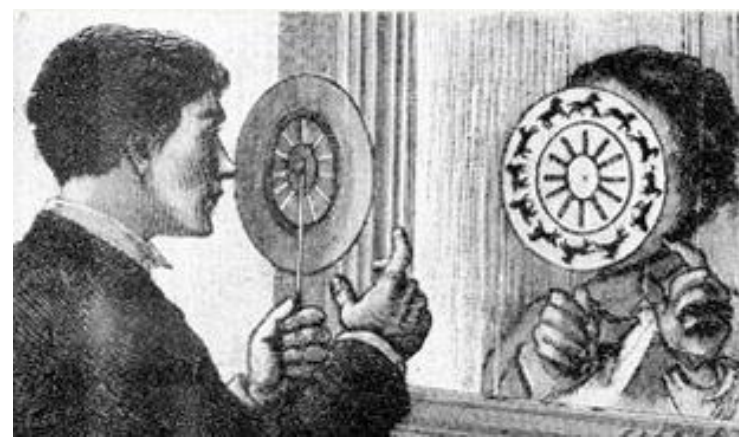

Şekil 7: Fenakistiskop çalışma mantığg (URL-7).

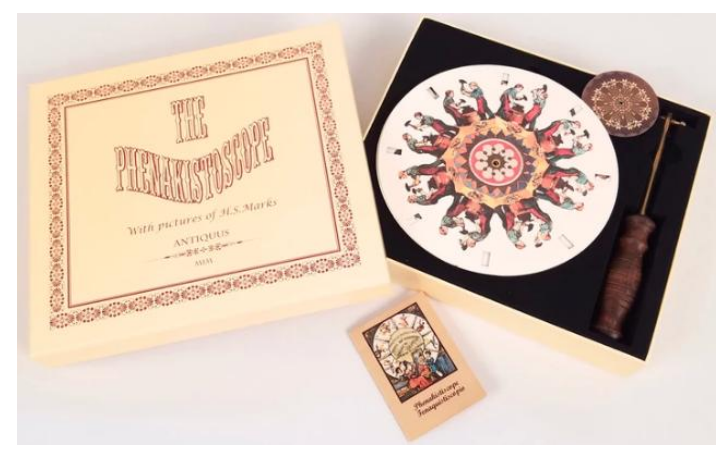

Şekil 8: Fenakistiskop (URL-8).

1800'lü yıllarda ortaya atılan optik oyuncaklardan biri de etrafinda şerit şeklinde eşit aralıklarla açılmış küçük göz yuvaları olan bir silindirden meydana gelen Zoetrop (zoetrope) 'tur. Zoetrop 'yaşam tekerleği' anlamına gelmektedir. 1833 yılında W. G. Horner ${ }^{10}$ tarafından geliştirilmiştir (URL-9). Alet, çalışma sistemi olarak diğer felsefi oyuncaklar gibi görmenin sürekliliği kuralından faydalanmaktadır. İçinde bir olayın farklı aşamalarını gösteren tasvirlerin bulunduğu bir bant bulunmaktadır ve silindir döndürüldüğünde, izleyicide silindir üzerindeki göz delikleri vasıtası ile hareket eden bir cismi izliyormuş algısı yaratılmaktadır (Şekil-9 ve Şekil-10).
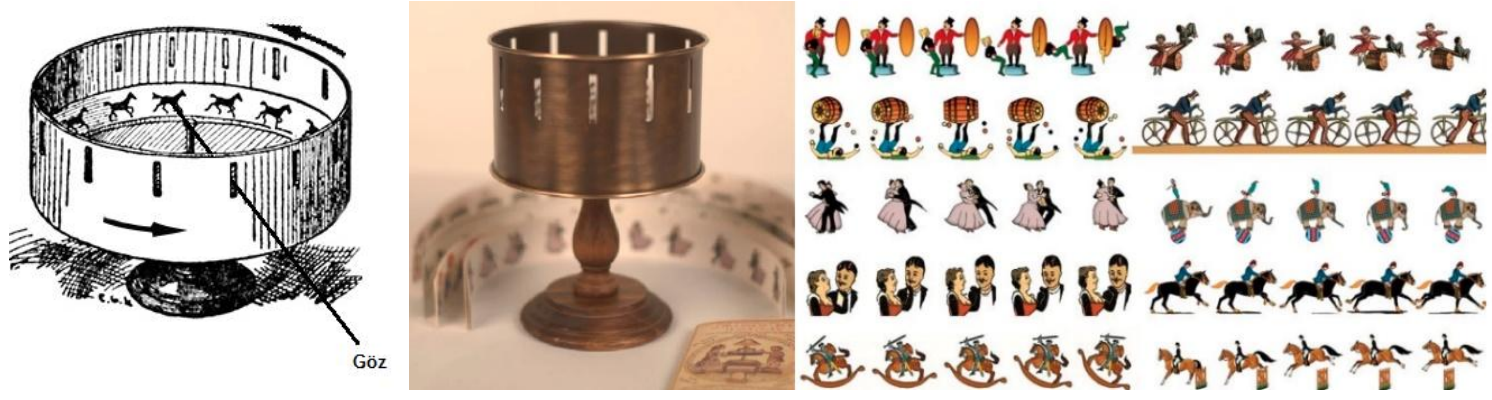

Şekil 9: Zoetrop çalışma mantığı (URL-10). Şekil 10: Zoetrop ve çeşitli zoetrop bantları (URL-11).

\footnotetext{
${ }^{8}$ Joseph Plateau (1801-1883). Belçikalı fizikçi.

${ }^{9}$ Simon Ritter von Stampfer (1792-1864). Avusturyalı fizikçi.

${ }^{10}$ William George Horner (1786-1837). İngiliz matematikçi.
} 
19. yüzyılın optik oyuncaklarından biri de Praksinoskop (praxinoscope) 'tur. Alet, 1876 ' da Reynaud ${ }^{11}$ tarafindan icat edilmiştir (URL-12). Parksinoskopta, zoetroptan farklı olarak silindirin ortasına yerleştirilmiş küçük bir silindir daha bulunmaktadır ve bu silindirin üzerinde her hareket için 12 ayrı ayna bulunmaktadır. İzleyici burada görüntüyü bandın yansıdığı ayna üzerinden gözlemleyebilmektedir (Şekil-11 ve Şekil-12).

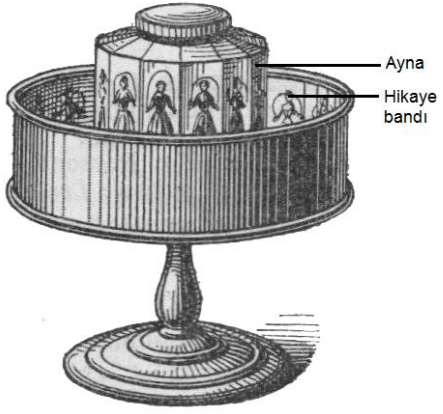

Şekil 11: Praksinoskop çalışma mantığı (URL-13).

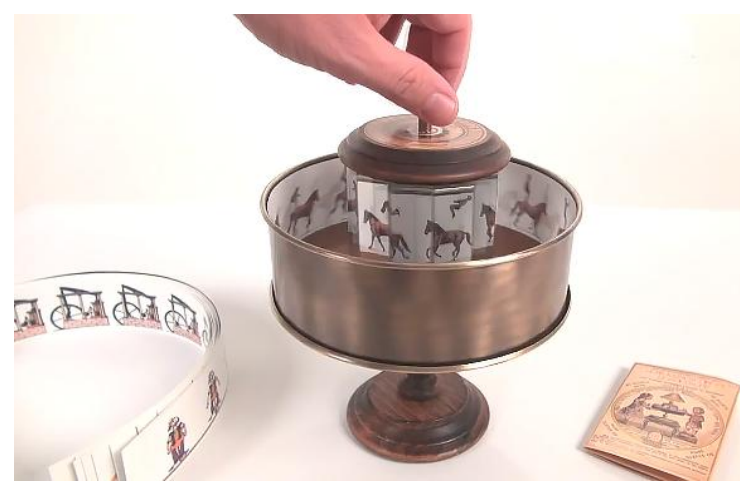

Şekil 12: Praksinoskop kullanımı (URL-14).

Daha önceki optik oyuncaklarda görüldügü üzere, bir nesnenin hareketini yüzey üzerinde ortaya çıkarmak için bu hareketi belli durumlarda çizmek veya fotoğrafını çekmek yeterli olmaktadır. Böylelikle resim dizisi bütüncül bir hareket olarak algılanabilmektedir. Görmenin sürekliliği kuralı gereğince görme sistemi, ardı ardına gördüğ̈̈ durağan resimleri hareket olarak algılama eğilimindedir. Muybridge, ${ }^{12}$ tarafından, 1877-1878 yılları arasında bir atın koşarken dört ayağının da yerden kesildiğini kanıtlamak amacı ile bir deney yapılmıştır. Bir koşu pistinin karşısına 24 adet fotoğraf makinesi yerleştirilmiştir. Her fotoğraf makinesinden koşu pistine bir ip çekilmiştir. Koşan at, ipleri sırası ile kopararak fotoğraf makinesinin çekim düğmesine basmıştır. Muybridge, böylece atın 24 ayrı fotoğrafını elde etmiş ve atların koşarken dört ayağının da yerden kesildiğini kanıtlamıştır (Kılıç, 2013, s. 120). Bu fotoğraflar gözlemci tarafından bir defterin sayfalarını hareket ettirir gibi belirli bir süre içinde art arda gözlemlendiğinde, gözlemleyicide görmenin sürekliliği kuralına göre atın hareketine dair bir izlenim yaratabilmektedir (Şekil-13).

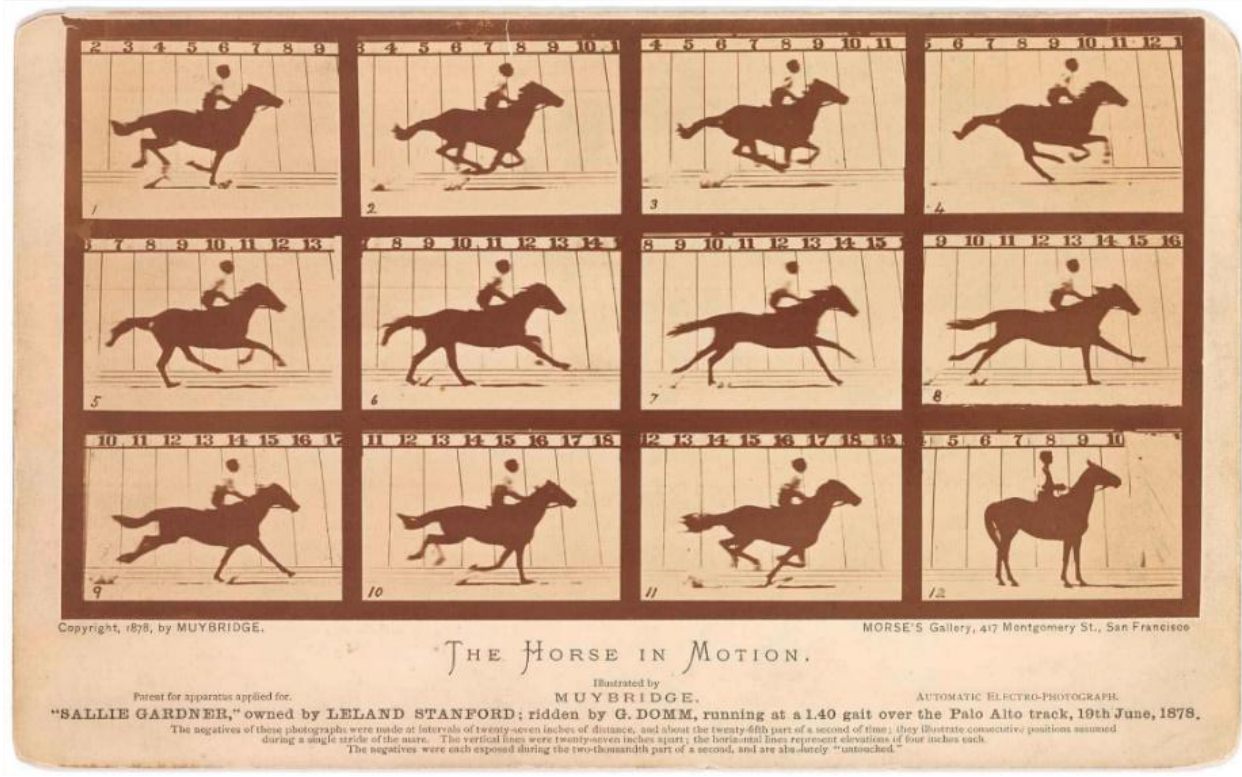

Şekil 13: Eadweard Muybridge koşan at çalışması (URL-15).

\footnotetext{
${ }^{11}$ Charles Emile Reynaud (1844-1918).

${ }^{12}$ Eadweard Muybridge (1830-1904). İngiliz fotoğrafç1.
} 


\section{İÇ MEKÂN TASARIMINDA MANIPÜLATIF ETKIILERIN OLUŞTURULMA YÖNTEMLERİ}

Y1lmaz (2004, s. 69-82); 'Mimari Mekânda Görsel Alg1 ve Manipülasyon İlişkilerinin İrdelenmesi’ adlı tezinde mimari mekânlarda manipülatif etkilerin, mekânın kullanıcı üzerinde duygulanım oluşturması ile mümkün olduğunu ifade etmektedir. Bu bağlamda mimari mekânın kullanıcı üzerinde duygulanım oluşturma yöntemlerini üç başlık altında toplamaktadır. Bunlar:

- Görsel algılamanın temel özellikleri ile oluşturulabilen manipülatif etkiler,

- Gestalt kanunlarından yararlanılarak oluşturulabilen manipülatif etkiler,

- Tasarım öğelerinden yararlanılarak oluşturulabilen manipülatif etkiler olarak sıralanmaktadır.

Yılmaz'ın tezinde ifade ettiği bilgiler ışığında, mimari mekânda manipülatif etkilerin oluşturulma yöntemleri şemalaştırılmıştır (Şekil-14). Daha sonra buradan çıkarımla manipülatif etkilerin daha kolay incelenebilmesi amacı ile bir tablo oluşturulmuştur (Şekil-15). Oluşturulan bu tablo yardımı ile yapılan çalışmanın bulguları tespit edilmiştir.

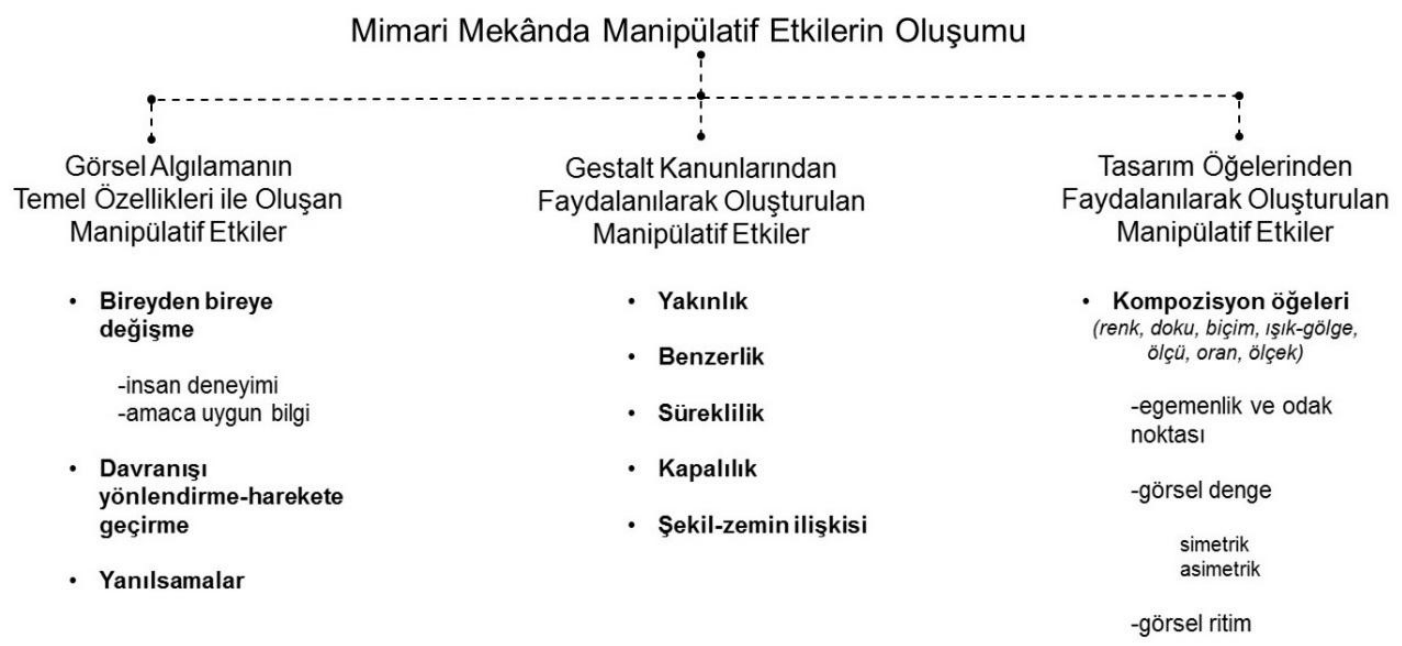

Şekil 14: Mimari mekânda manipülatif etkiler oluşturulma yöntemleri. Tablo yazar tarafindan Y1lmaz (2004, s. 6982)'ın bu alanda yaptığı araştırma referans alınarak oluşturulmuştur.

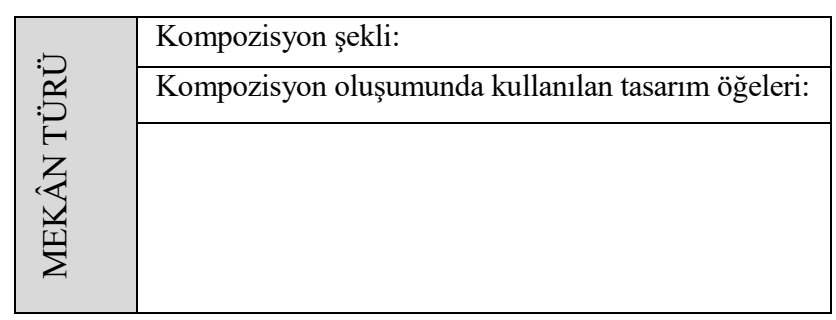

Şekil 15: İç mekânda tasarım öğelerinden faydalanılarak oluşturulan manipülatif etkilerin incelenmesi amacı ile oluşturulan tablo.

Görsel algılamanın temel özellikleri ile oluşan manipülatif etkiler bireyin görme algısı ile doğrudan ilişkilidir. Yöntemin alt başlıklarından 'bireyden bireye değişme' görme duyumunun kişinin geçmişte edindiği deneyimler ve sahip olduğu kültürel birikime işaret etmektedir. Bu bağlamda iç mekân tasarımcısı bireysel tasarımlarda kişinin geçmişini ve deneyimlerini, kamusal tasarımlarda ise toplumsal bilinci ve toplum geçmişini göz önünde bulundurmak durumundadır. Bu yolla tasarımcı, kullanıcı kitleye hitap eden tasarımlar ortaya koyabilecek, oluşturduğu mekânın kullanıcıda ne gibi izlenimler yaratabileceğini yönlendirebilecektir. 'Davranışı yönlendirme-harekete geçirme' başlı̆̆ ise görsel algının bireyin hislerine ve davranışlarına etki ettiğini işaret etmektedir. Örneğin iç mekân tasarımcıları bu yöntem yolu ile kamusal alanlarda çizgisel elemanlarla bireylerin dolaşım yönlendirmelerini sağlayabilmektedir. 'Yanılsamalar' başlığı ise bireyin çevreden aldığı duyumların beyinde yanlış 
yorumlanması yolu ile ortaya çıkabilmektedir. Tasarımın etkisini artırmak veya farklı yönlerine dikkat çekmek amacı ile bu yöntem günümüzde tasarımcılar tarafindan bilinçli olarak sık sık kullanılmaktadır.

Gestalt kanunlarından faydalanılarak oluşturulan manipülatif etkiler yakınlık, benzerlik, süreklilik, kapalılık, şekil-zemin ilişkisi gibi alt başlıklara ayrılmaktadır. Yakınlık ilkesi, birbirine yakın iki nesnenin grup olarak algılanmasıdır. Benzerlik ilkesi, benzer nitelikteki nesnelerin grup olarak algılanmasını ifade etmektedir. Süreklilik ilkesi, aynı yöndeki nesnelerin grup olarak algılanması durumunu ifade etmektedir. Kapalılık ilkesi, kapalı bir şekil oluşturan nesnelerin grup olarak algılanmasını ifade etmektedir. Şekil zemin ilişkisi ise, nesnenin şeklinin içinde bulunduğu zemin aracılığı ile algılanabilmesi durumunu ifade etmektedir. Günümüzde iç mekân tasarımcıları gerçekleştirdikleri mekân tasarımlarında mekânı kullanıcıya doğru bir biçimde algılatma hususunda bu ilkelerden yararlanabilmektedirler.

Tasarım öğelerinden yararlanarak oluşturulan manipülatif etkiler ise kompozisyon öğeleri olan renk, doku, biçim, 1şık-gölge, ölçü, oran ve ölçek öğeleri ile gerçekleştirilmektedir. Bu kompozisyon öğeleri ile 'egemenlik ve odak noktası', 'görsel denge' ve 'görsel ritim' gibi kompozisyonlar oluşturmak mümkündür. $\mathrm{Bu}$ öğelerle iç mekân tasarımcısı mekân kullanıcısının davranışlarını ve duygularını yönlendirebilmektedir. Örneğin mekânın kullanıcının dikkatini çekmesi istenilen noktasında egemenlik ve odak noktası oluşturulması yöntemi ile mekân kullanıcısı yönlendirilebilecektir.

\section{BILLIMKURGU FÍLMLERINDE İÇ MEKÂNDA TASARIM ÖĞELERINDEN FAYDALANILARAK OLUŞTURULAN MANIPÜLATIF ETKILER: MATRIX ÖRNEĞİ}

Matrix filmi, 1999 yılında gösterime girmiştir. Matrix Reloaded (2003) ve Matrix Revolutions (2003) ile birlikte üç sinema filminden oluşan Matrix serisinin ilk filmidir. Filmin senaristliğini ve yönetmenliğini Lana ve Lily Wachowski gerçekleştirmiştir. Filmin sanat yönetmenliği ise, Hugh Bateup ve Michelle McGahey tarafindan gerçekleştirilmiştir.

Yapılan bu çalışmada; Matrix filmi, tasarım öğelerinden faydalanılarak oluşturulan manipülatif etkiler kapsamında incelenecektir. Manipülasyon bağlamında incelenmeye değer görülen film iç mekân sahneleri Şekil 15 'teki tablo aracılı̆̆ ile değerlendirilecektir.

Matrix; bireyin tüm yaşamını, devamlı bir uyku benzeri felç durumunda, beyin uyaranlarınca yaratılan alg1 yanılsamaları içerisinde sürdürdüğü bir yerdir. Bilgisayarlarca üretilen bu düş dünyasında yaşayan bireyler, hayatı bilindik şekilde tecrübe ettiklerine inanmaktadırlar. Bireylerin duyu alıcıları Matrix'e bağlıdır. Böylelikle duyuları Matrix’te deneyimledikleri yaşayışa uygun biçimde bilgisayarlar tarafindan uyarılmaktadır (Korsmeyer, 2003, s. 51). Bu süreçte ise robotlar adeta tarlalardaki ekinler gibi olan insanlardan enerji elde etmektedir. Sürekli devam eden sistematik algı yanılsaması destekli bu mekân simülasyonu sayesinde robotlar kesintisiz olarak insanlardan enerji elde edebilmektedir. Ölen insanlar ise sıvılaştırılmakta ve yaşayan insanlar bu sıvı ile damardan beslenmektedir.

Film, zaman ve mekân bağlamında incelendiğinde; iki ayrı zaman dilimini kapsadığı görülmüştür. Birincisi 1999 senesinin yaşandığ Matrix evreni, diğeri ise 2199 senesinde olunduğu tahmin edilen Zion şehrinin yer aldığı gerçek evrendir. Mekân bağlamında ise filmde üç ana mekân bulunduğu gözlemlenmiştir. Bunlarda ilki; kişilerin duyusal manipülasyona maruz kalarak zihnen bağlandıkları ve böylelikle burada var olduklarını düşündükleri ve gerçekliği genellikle değişmeyen 'sahte mekân' Matrix, diğeri; Matrix benzeri olan fakat karakterlerin alacağı eğitime veya deneyimlemek istedikleri eyleme göre biçim değiştiren 'ara mekân' bilgisayar arayüzü, bir diğeri ise Matrix evreninin manipülasyonundan koparak ulaşılabilecek olan 'gerçek mekân'dır. Film içerisinde kullanılan renk ve dokularla bu mekânlar arası farkların belirginleştirildiği gözlemlenebilmektedir. 


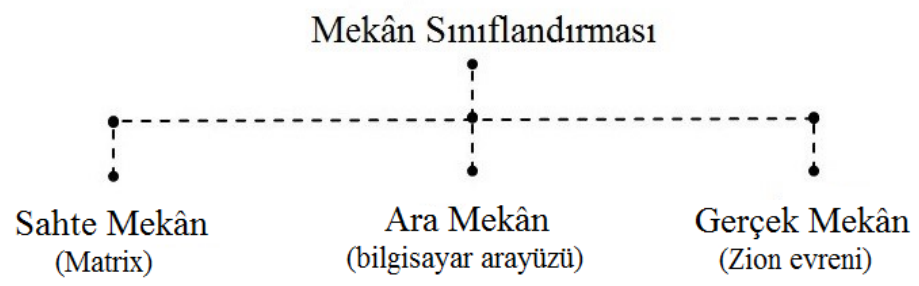

Şekil 16: Matrix filmi mekân bölümlenmeleri.
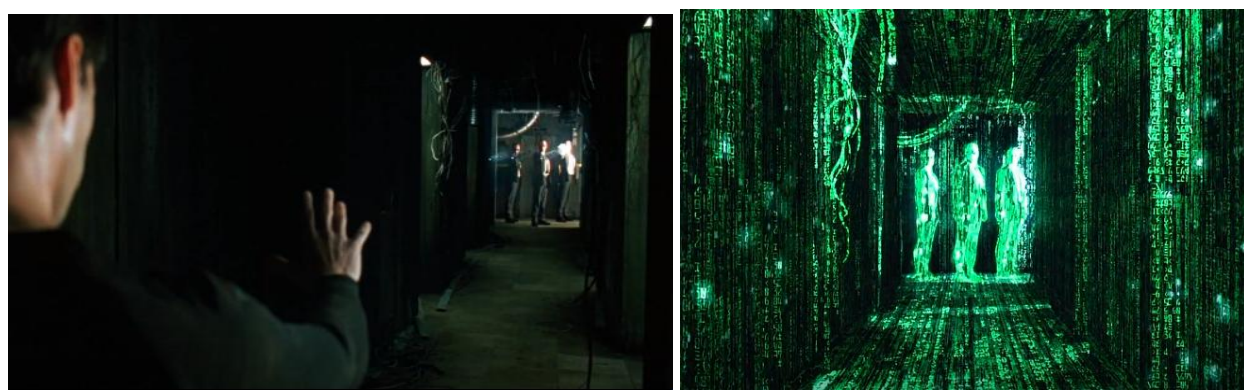

Şekil 17: Sahte mekân örneği Matrix (solda) ve bu evrenin gerçekte nasıl göründüğünü ifade eder görsel (sağda) (Wachowski ve Wachowski, 1999).

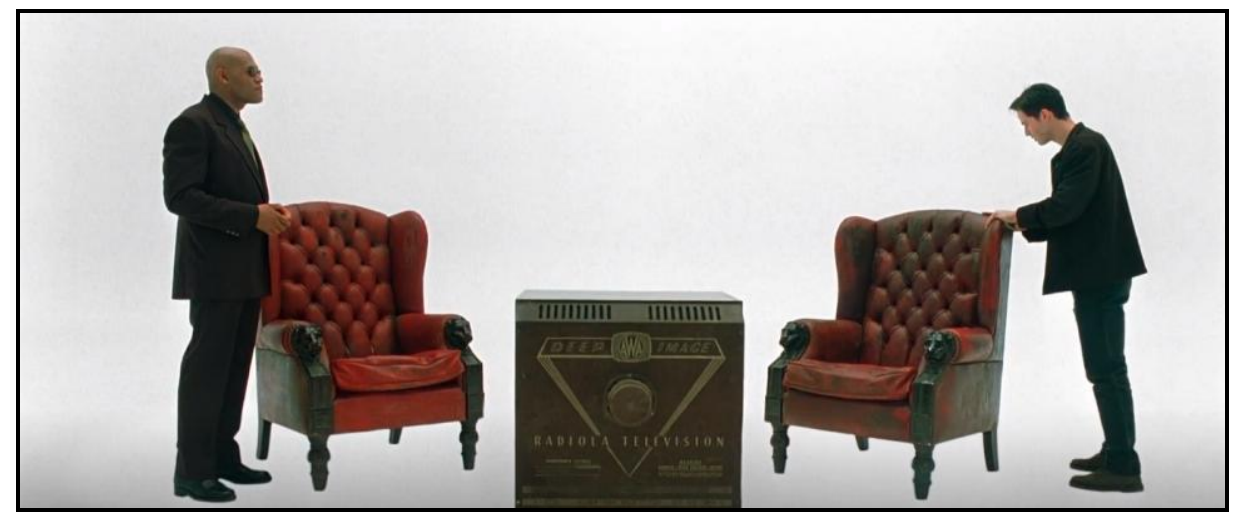

Şekil 18: Ara mekân bilgisayar programı ile yönlendirilebilmektedir. Matrix'in aksine bu uzam istek ve ihtiyaca göre şekil değiştirebilmektedir (Wachowski ve Wachowski, 1999).

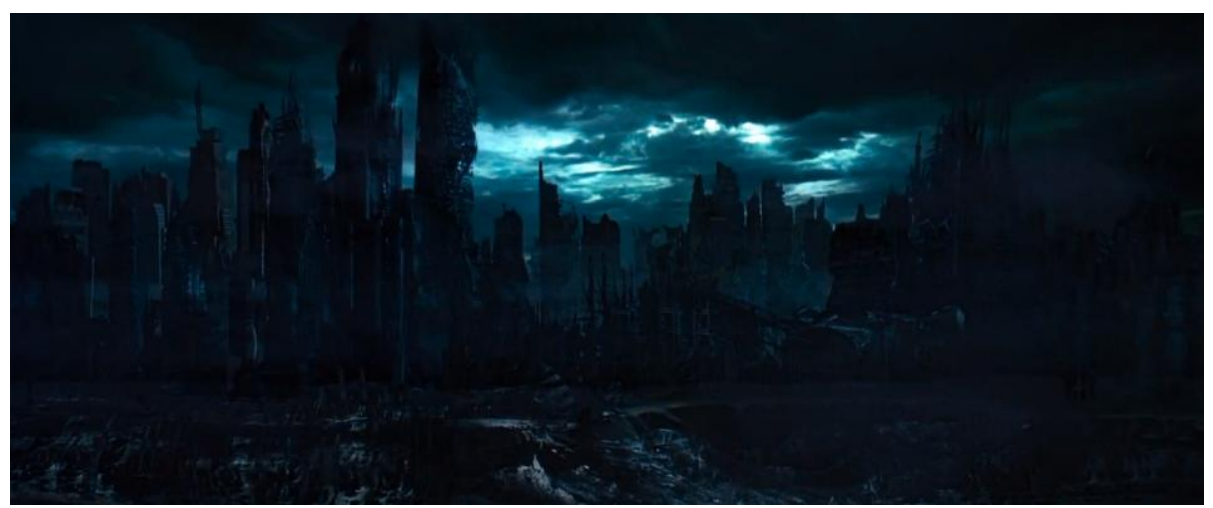

Şekil 19: Gerçek mekân, Matrix’in aksine kaotik bir görüntüye sahiptir ve yaşam koşulları oldukça zorlayıcıdır (Wachowski ve Wachowski, 1999). 


\section{BULGULAR}

Çalışmada; kompozisyon oluşumunda kullanılan ana ve yardımcı öğelerin daha kolay okunabilmesiyorumlanabilmesi adına, ana öğeler bold ve italik yazı tipi ile gösterilmiştir.
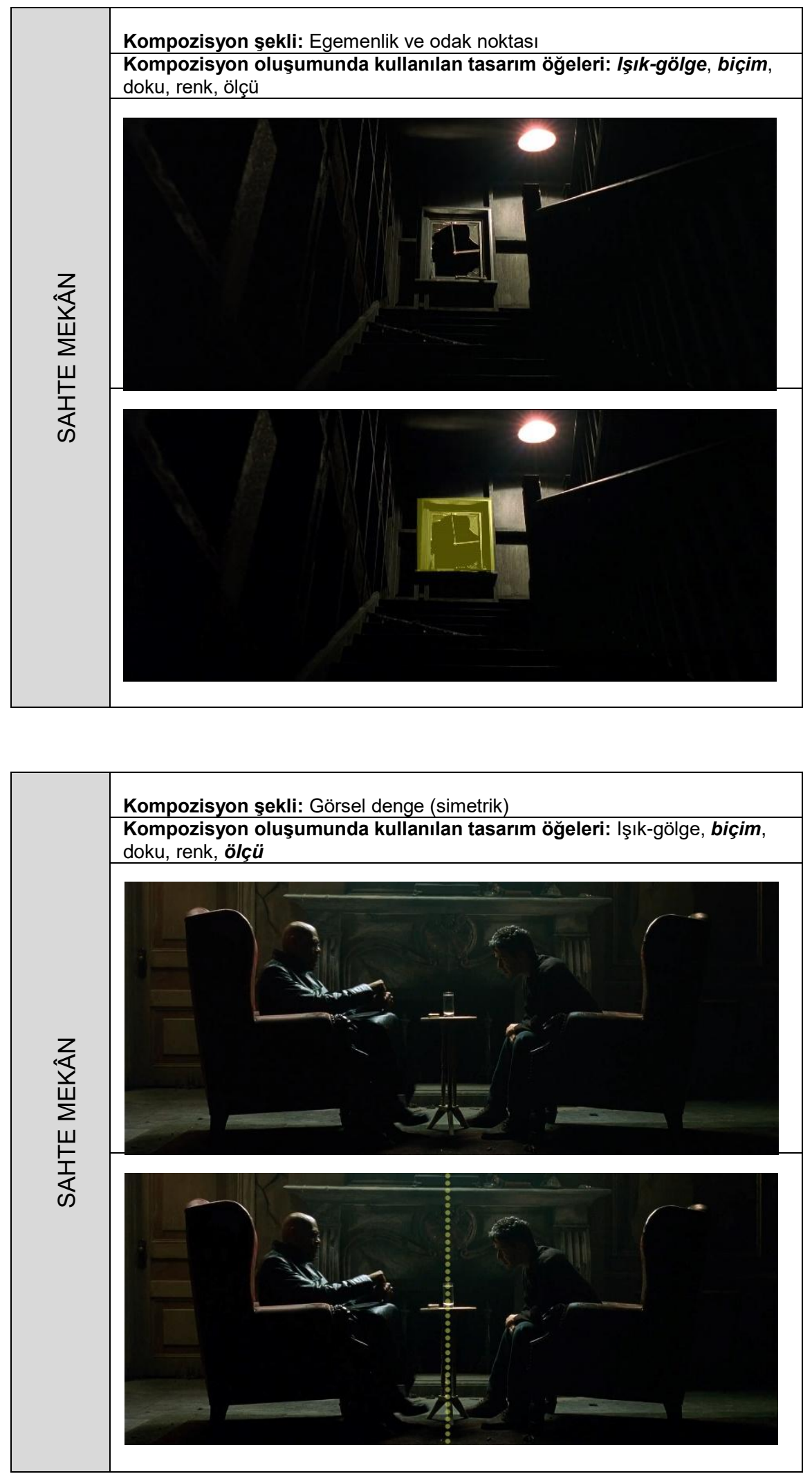

IBAD Sosyal Bilimler Dergisi / IBAD Journal of Social Sciences, (6), Kış/Winter 2020 

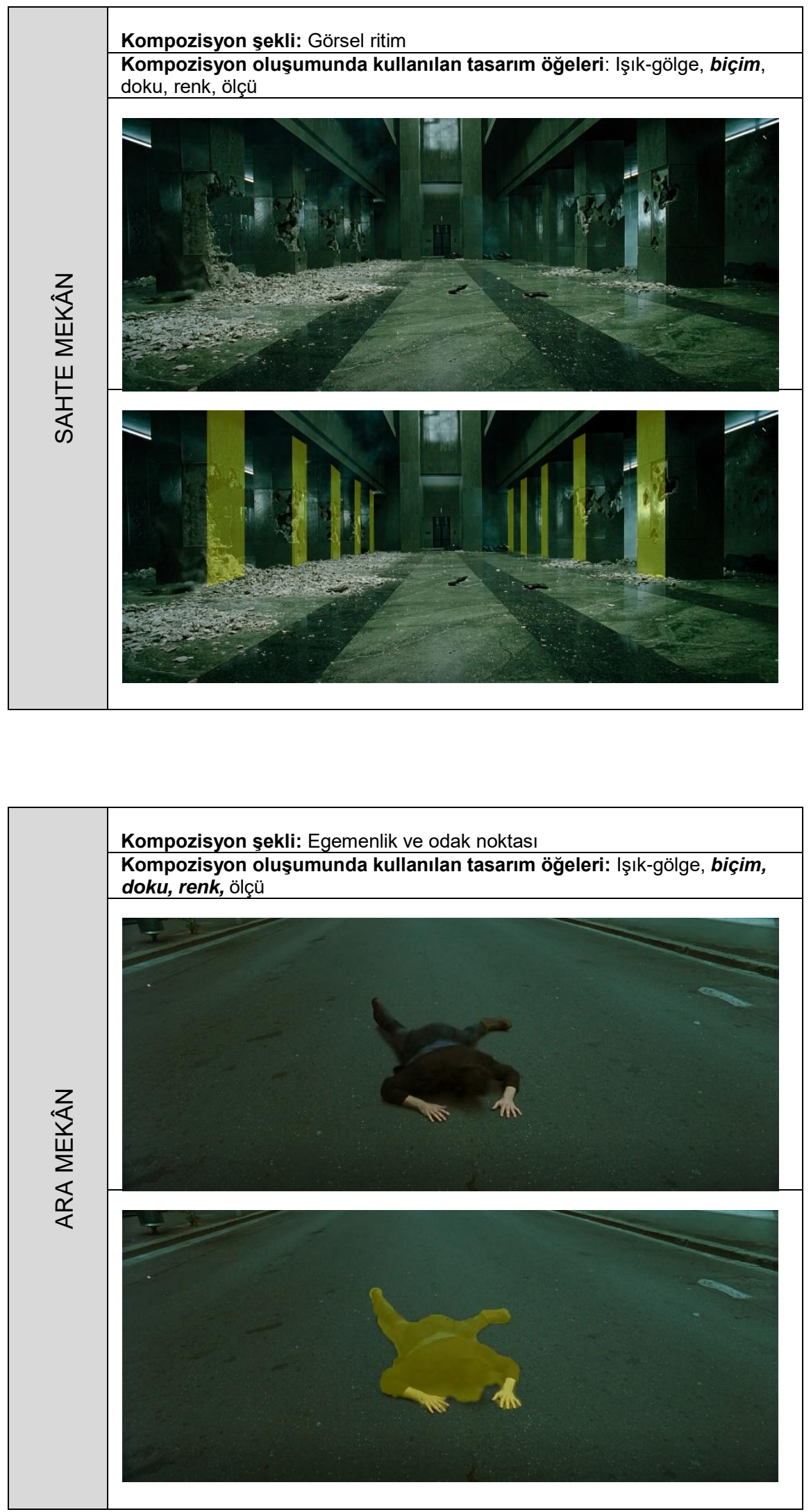

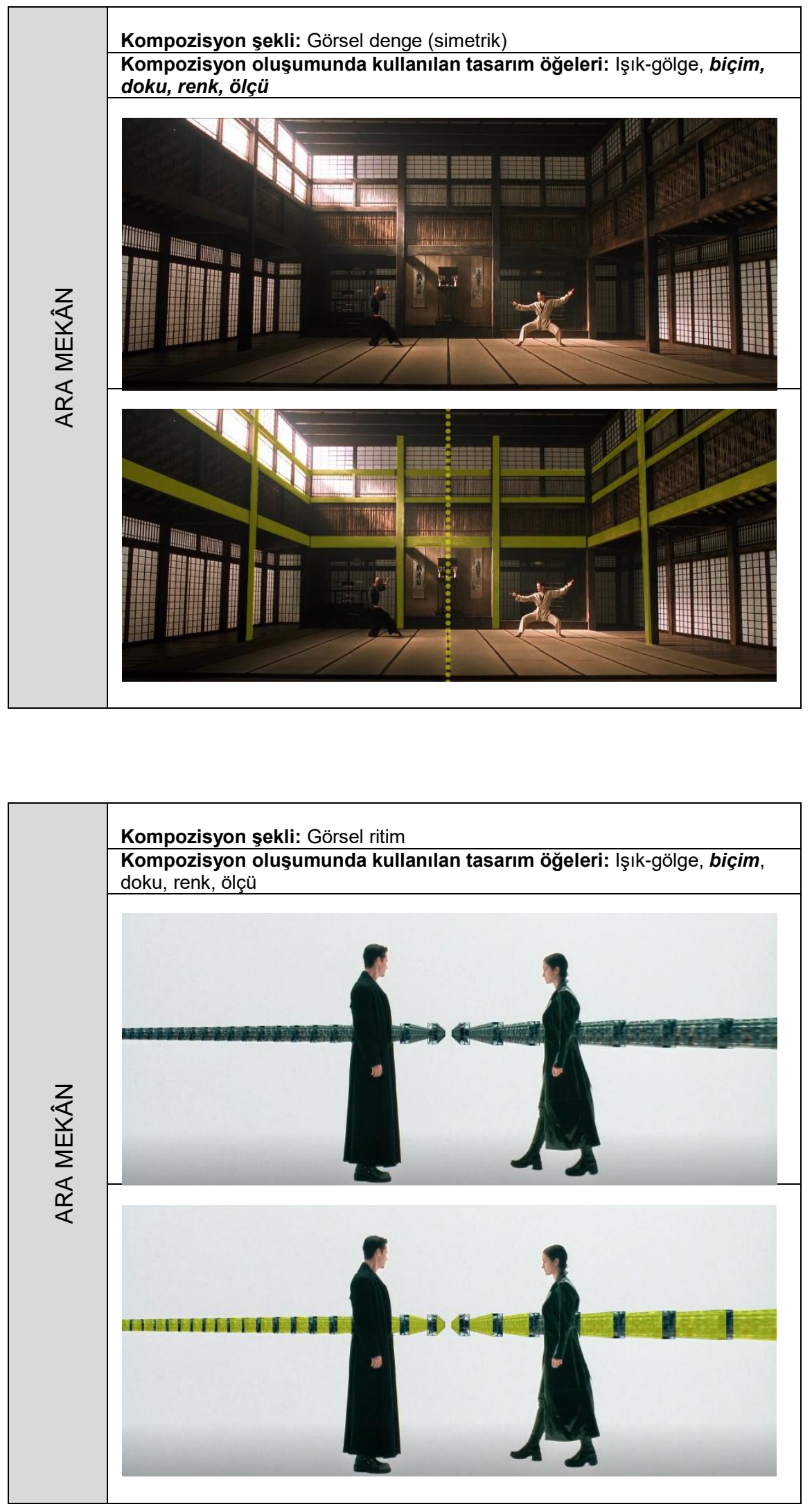

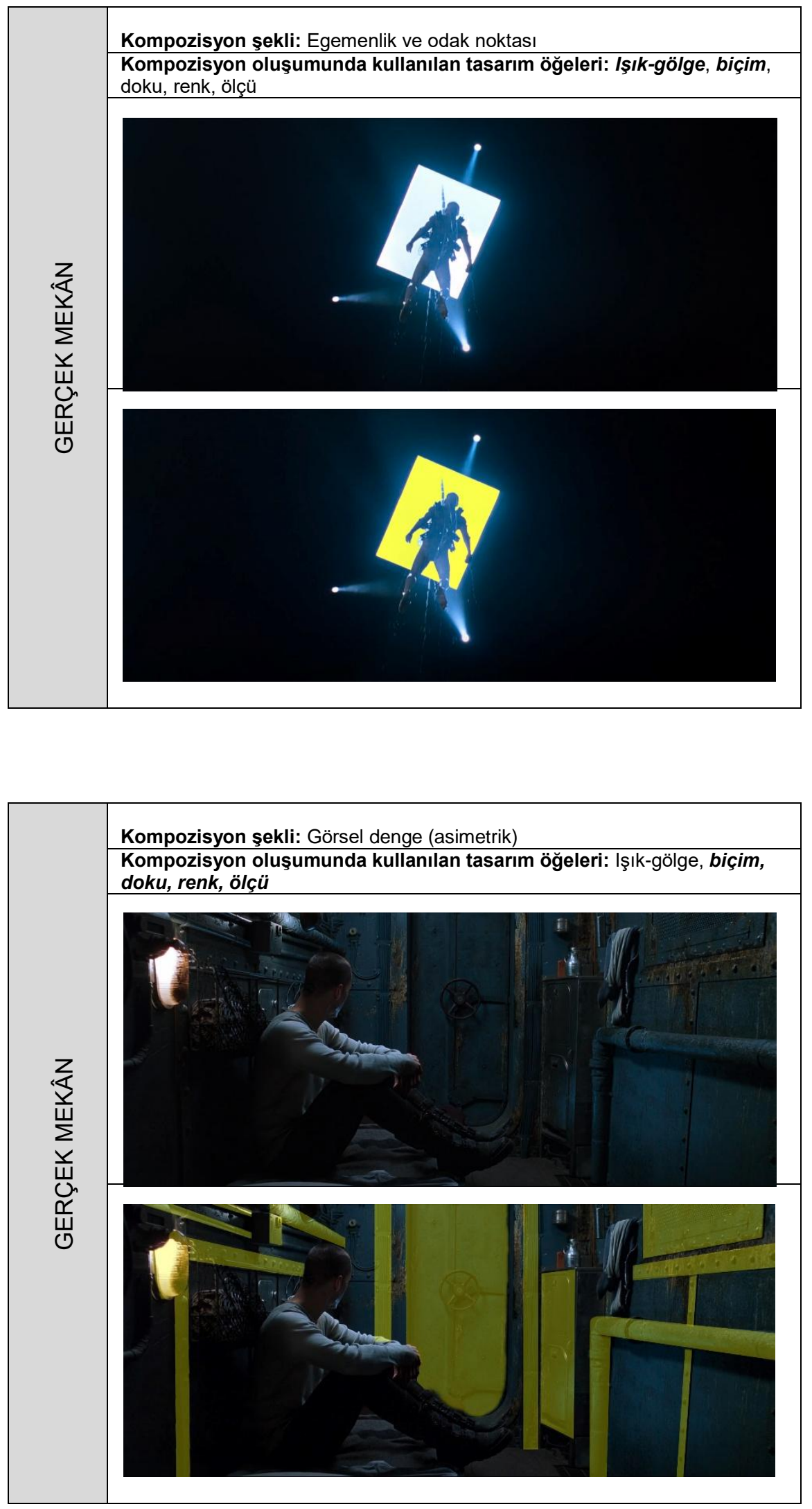


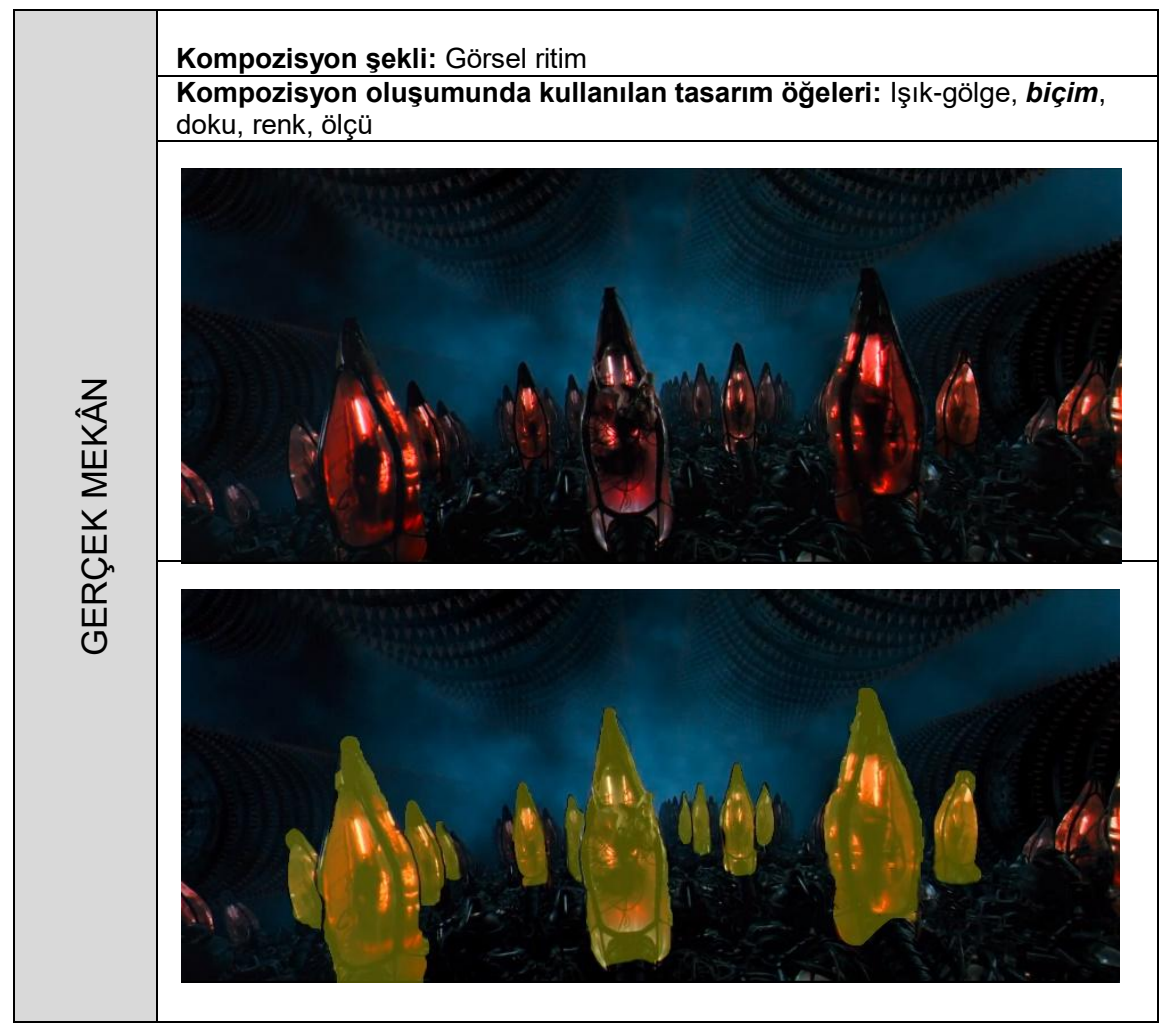

\section{SONUÇ VE ÖNERILER}

Yapılan bu çalışmada; Matrix filmi üzerinden, bilim kurgu filmlerindeki iç mekânların bireyler üzerinde hangi yollarla manipülatif etkiler oluşturduğu araştırılmıştır. Bu amaçla filmin uygun görülen sahneleri üzerinden; tasarım öğelerinden faydalanılarak oluşturulan manipülatif etkilerin, hangi kompozisyon şeklini hangi tasarım öğeleri aracılığı ile gerçekleştirdiği araştırılmıştır. Araştırma sonucunda görülmüştür ki, bir bilim kurgu filmi olan Matrix’te; izleyiciye hikâyenin istenildiği gibi algılatılabilmesi için, tasarım öğelerinden faydalanılarak oluşturulan manipülatif etkilerden; egemenlik ve odak noktası, asimetrik ve simetrik denge ve görsel ritim oluşturma yöntemlerinin tümü kullanılmıştır. Bu yöntemler kullanılırken de kompozisyon oluşumunda tasarım öğelerinin tümünden faydalanılmış olduğu gözlemlenmiştir. Bu durum, iç mekân tasarımcılarına iç mekân yaratımlarında manipülasyon öğelerinin ne gibi şekillerde kullanılabileceğine dair fikir verebilmektedir. İç mekân tasarımcısı, insanları bu yöntemler aracılığı ile iç mekân özelinde manipülatif olarak etkileyerek mekânın işlevini güçlendirebilecektir.

Mekânsal sınıflandırma olgusu, incelemeye konu Matrix filmi için izleyiciye hikâye aktarımı hususunda ön plana çıkan bir unsurdur. Film yolu ile aktarılan hikâyedeki kişilerin, bahsedilen bu mekânlara ait deneyimleri, tasarım öğelerinden faydalanılarak oluşturulan mekânsal manipülasyon öğeleri ile izleyiciye sezdirilmekte ve aktarılan hikâyede alt metin olarak yer almaktadır.

İç mekân tasarımı hususuna gelindiğinde ise, kullanıcılara mekânsal öğeler aracılığı ile mekânın sunduğu deneyimin, mekânda gerçekleştirilmesinin amaçlandığı işlevin bir nevi 'sezdirildiği' ifade edilebilmektedir. Bu durumu, mekânların da manipülasyon öğeleri kullanımı ile tıpkı filmlerde olduğu gibi alt metinlerinde yer alan hikayelerini kullanıcılarına sezdirdikleri şeklinde yorumlamak mümkündür. İç mekân ve bir görsel sanat ürünü olan sinema, bu sezdirilme işlemini izleyiciyi/kullanıcıyı görsel olarak etkileyebilecek unsurlar aracılığı ile gerçekleştirmektedir. İç mekân tasarımcısı, bu iki farklı alan arasında kurulan ortaklıktan mekânın kullanıcıya doğru aktarımı hususunda faydalanabilecektir. 
Çalışma sonucunda elde edilen bulgular incelendiğinde; egemenlik ve odak noktası kompozisyonu oluşturma hususunda 'biçim' öğesinin; sahte mekân, ara mekân ve gerçek mekân unsurlarının her üçünde de ana öğe olarak kullanıldığı saptanmıştır. Görsel denge oluşturma hususuna gelindiğinde ise; yine her üç mekânda da 'biçim ve ölçü' unsurlarından faydalanıldığı görülmüşsür. Mekân sınıflarında görsel ritim kompozisyonu oluşturma hususunda ise yine her üç sınıfta da 'biçim' öğesinin ana unsur olarak ön plana çıktığı saptanmıştır. Bunun dışında herhangi bir öğede mekânsal sınıflandırma unsuru üzerinde anlamlı bir ortaklık gözlemlenmemiştir.

Biçim öğesinin her mekân sınıfında ve her kompozisyon şeklinde ön plana çıkması, iç mekân tasarımcısının biçim tasarlarken mekânın anlatımında bu unsurdan doğru bir biçimde faydalanmasının önemini vurgular niteliktedir. İç mimarın, bu unsuru ve diğer kompozisyon oluşturma unsurlarını doğru bir biçimde kullanarak, mekânda dair doğru çözümlenmiş bir bilişsel alt metin oluşturabileceği ortadadır.

Gelecekteki araştırmacılara tarihsel süreçte bilim kurgu filmlerinin mekânsal manipülasyon bağlamında incelenmesi önerilebilmektedir. Böylelikle bilim kurgu türünde temsil edilen geleceğin mekânlarında yaratılan görsel manipülasyona dair verilerin tarihsel süreç içinde değişimine dair okumalar yapılabilecektir. Bu yolla ise, mekânsal manipülasyonun geleceğine dair öngörülerde bulunabilecektir.

\section{KAYNAKÇA}

Arnheim, R. (2015). Görsel düşünme (1. Bask1). İstanbul: Metis Yayınları.

Bektaş, E.H. (2017). Sinema ve mekân ilişkisi açısından bilim kurgu filmlerine bir bakış. Mimarlık ve Yaşam Dergisi, 2(2), 201-218.

Berger, J. (2017). Görme biçimleri (24. Baskı). İstanbul: Metis Yayınları.

Buğdaycı, İ. (2008). Optik yanılsama. Bilim ve Teknik Dergisi Yıldız Takımı Eki, (2), 14-17.

Kı1lı̧, L. (2013). Görsel kültür (2. Baskı). Eskişehir: Anadolu Üniversitesi.

Kirschner, J. Manipülasyon ama nasıl? (1. Baskı). Çev. Aydın Arıtan. İstanbul: Arıtan Yayınevi.

Korsmeyer, C. (2003). Matrix ve felsefe (1. Bask1). İstanbul: Güncel Yayınc1l1k.

Groh, M. J. (2017). Mekân yaratmak (2. Bask1). İstanbul: Metis Bilim.

Özön, N. (1984). 100 Soruda sinema sanatı (2. Baskı). İstanbul: Gerçek Yayınevi.

Özön, N. (1985). Sinema uygulayımı- sanatı tarihi (1. Baskı). Ankara: Hil Yayın.

Schwab, K. (2019). Dördüncü sanayi devrimini şekillendirmek (1. Baskı). İstanbul: Optimist.

Silver, J. (Yapımcı) ve Wachowski, L., Wachowski, L. (Yönetmen). (1999). Matrix [Sinema filmi]. ABD: Warner Bros.

Tesla, N. (2017). Tesla-aforizmalar (1. Bask1). İstanbul: Zeplin Kitap.

Yıldırım, S. (2012). Bilim kurgu filmlerinde mekân öğelerinin biçimlenişiyle gelecek algısının oluşturulması üzerine bir araştırma. Yayımlanmamış yüksek lisans tezi, Hacettepe Üniversitesi Sosyal Bilimler Enstitüsü, Ankara.

Yılmaz, Ö. (2004). Mimari mekânda görsel algl ve manipülasyon ilişkilerinin irdelenmesi. Yayımlanmamış yüksek lisans tezi, Yıldız Teknik Üniversitesi Fen Bilimleri Enstitüsü, İstanbul.

URL-1: https://mymodernmet.com/webcomic-architects-leewardists/ erişim tarihi: 28.10.2019

URL-2: http://precinemahistory.net/900.htm erişim tarihi: 19.10.2019

URL-3: http://paxonbothhouses.blogspot.com/2014/12/brunelleschis-dome-wikipedia-httpen.html erişim tarihi: 19.10 .2019

URL-4: https://whatilearnonthursdays.wordpress.com/2013/11/27/animation-thaumatrope/ erişim tarihi: 19.10.2019

URL-5: https://graphicarts.princeton.edu/2013/10/28/thaumatrope/ erişim tarihi: 19.10.2019 
URL-6: http://www.mhs.ox.ac.uk/exhibits/fancy-names-and-fun-toys/phenakistiscopes/ erişim tarihi: 20.10.2019

URL-7: https://www.instructables.com/id/Discover-the-Phenakistoscope-a-Vintage-Animation-S/ erişim tarihi: 20.10 .2019

URL-8: https://ancientmagictoys.com/products/classic-phenakistoscope-box-set erişim tarihi: 20.10.2019

URL-9: http://www.mhs.ox.ac.uk/exhibits/fancy-names-and-fun-toys/zoetrope/ erişim tarihi: 20.10.2019

URL-10: http://jasonevans342.blogspot.com/2016/09/zoetrope.html erişim tarihi: 20.10.2019

URL-11: https://ancientmagictoys.com/products/classic-brass-zoetrope erişim tarihi: 20.10.2019

URL-12: http://www.mhs.ox.ac.uk/exhibits/fancy-names-and-fun-toys/praxinoscope/ erişim tarihi: 20.10.2019

URL-13: https://mpenningtonvt2p1.wordpress.com/2014/12/08/praxinoscope/ erişim tarihi: 20.10.2019

URL-14: https://ancientmagictoys.com/products/classic-brass-praxinoscope erişim tarihi:20.10.2019

URL-15: http://100photos.time.com/photos/eadweard-muybridge-horse-in-motion erişim tarihi: 19.10.2019 